of a gale such as would just blow a kite line from ship to shore needs reconsideration.

Little has been published about Prof. Langley's experiments beyond a reference to the accident which gave Prof. Manley a premature bath in the Potomac.

The idea of combining a glider and boat was tried initially with success and ultimately with failure by Herr Kress on a reservoir a few miles out of Vienna, near the main railway line from Germany. Major Baden-Powell has adopted the same plan at the Crystal Palace. The machine descends a kind of chute from a height of about thirty feet, and is shot off into the air about six feet above the water. With this small height it is not unlikely that successful glides might be made even if the steady motion were longitudinally unstable, for by careful projection several wave-lengths might safely be described in the air before the pitching became dangerous.

It is probable that a motor driven machine travelling at high speed would be much more stable than a gravity machine, but to understand the management of the machine is a necessary condition of success, and the more this can be made the subject of mathematical study the easier will the task be for an aëronaut who is perfectly familiar with the equations of motion. In regard to the effect of speed on stability, the pretty butterfly-like "helicoptera" driven by elastic must not be quoted as instances. They raise themselves nearly vertically; we are concerned with machines moving nearly horizontally.

From all that has been said above it will be seen that there is plenty of work to be done in connection with aërial navigation. At the present time, careful quantitative measurements of the coefficients of stability of actual machines by attaching them to whirling tables are even more needed than further balancing experiments in mid-air.

\section{G. H. BRYAN.}

\section{PHAISTOS AND HAGIA TRIADA, CRETE.}

$\mathrm{N}$ the south of Central Crete, a day's journey from 1 Candia on a good horse, lies the scene of discoveries no less important than those of Dr. A. J. Evans at Knossos. They consist of the ruins of two palaces, one large and one small, but both built on the same general plan and with the same materials (stone and concrete) as that which has made Dr. Evans famous. There can be no doubt that all three belong to one age and one social system; that they were under one Government is clear from the fact that none of the three were fortresses. Crete was, in fact, as Thucydides told us long ago, a sea-power which had no fear of assault by land. With the architectural or historical interest of these remains we need not concern ourselves at present, nor with the general character of the articles found in them. In all three we meet with vessels of use and ornament, painted frescoes, inscribed blocks or tablets, seals, human and animal figures, and articles of domestic or religious character. But in or near Hagia Triada there came to light a number of objects of special interest which distinguish that palace, smallest of the three, above the others.

First there is a sarcophagus of stone, painted upon all four sides. Each of the two ends bears a chariot in which are two female figures; a pair of horses draws one, a pair of griffins the other. The two sides bear a representation of sacrifice to the dead. Men leading animals-bull, goat, or sheep-women with baskets of fruit, others with bowls apparently full of wine or some other liquid, which is being poured into a large jar; a flutist and a harper, playing upon NO. I 846 , VOL. 7 I] a lyre of seven strings (which are therefore older than Terpander by a thousand years); men carrying animals in their arms; and lastly the dead man himself, standing beside a tree before his own tomb and receiving the pious offerings. A most noteworthy fact in this representation is that the men wear women's skirts.

Next come three vases of steatite, each bearing a scene carved in relief. The workmanship of these carvings is astonishing for its finish, and the designs are full of life, reminding us not distantly of good Attic work. On one vase a couple of youths stand face to face, one leaning upon a spear or staff, the other bearing over his shoulders a staff and a whisk of some sort. Both are naked, save for the familiar loincloth of the Mycenæans (which the Greeks never wore, except in the very earliest times at the Olympian games), and high boots of the same kind which are still worn in Crete and always have been. The second vase represents several pairs of men, some wrestling and some boxing, and a bull-hunt or bull-baiting. The boxers have their hands bound about with straps of leather, or something like a fingerless glove. Some of these men wear helmets, which in part at least seem to be made of metal; and helmets hitherto have been undreamt of at this period.

But the last vase is the most striking of all. It bears a procession of men marching two and two, led by a personage clad in a stiff bell-shaped tunic covered with scales. He is bareheaded and carries a long staff or sceptre resting upon his shoulder. The men behind him wear flat caps something like to a turban, and loincloths, and each carries over his left shoulder a long pole branching out into three long flexible wands at the end. In the middle of the procession are four men singing, one bearing the sistrum of Isis; these have no wands. Some see in this a triumphal procession of soldiers after war. The lack of arms or shields makes this unlikely; the threepronged objects can hardly be weapons, for they seem to be flexible, but what they are it is impossible to say. Those are more likely to be right who believe it to be a harvest festival of some kind, and the threepronged implement an implement used in some harvesting process. If we may assume that these objects have no use at all, but are ornamental (which is not likely), the whole might be a religious procession without regard either to war or husbandry.

\section{NOTES.}

THE Bakerian lecture of the Royal Society will be delivered by Dr. Horace T. Brown, F.R.S., on March 23, upon the subject of "The Reception and Utilisation of Energy by the Green Leaf."

IT is proposed to erect in Jena a memorial to Prof. Ernst Abbe, so that all who see it may be reminded of his great services to optical science and industry, and his sterling qualities as a man. Abbe's work and influence are appreciated wherever physical science and sociology are studied, and there should be no difficulty in obtaining sufficient funds to raise a noble monument to his memory. The committee organised for this purpose includes the names of Dr. Czapski, Dr. Eggeling, Dr. G. Fischer, Prof. Rosenthal, and Prof. Winkelmann. Subscriptions for the memorial should be sent to the treasurer, Dr. Gustav Fischer, Jena.

Science states that the Prussian Academy of Science has awarded its Helmholtz medal to Prof. Ramón y Cajal, professor of neurology at Madrid. 